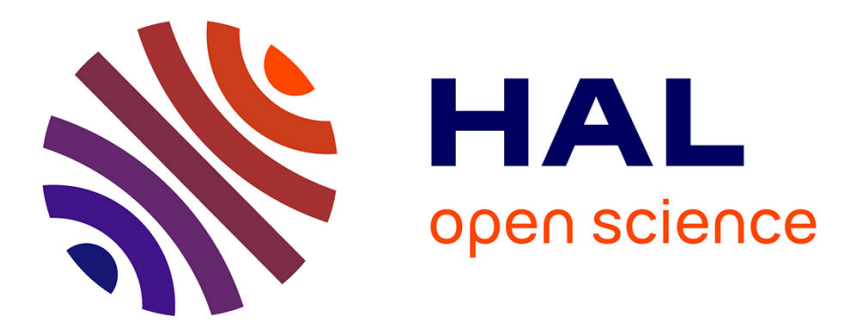

\title{
Nitrochalcones as organogelators : evidence of the involvement of nitro groups and solvent in gel formation
}

F.X. Simon, Th. Nguyen, M. Schmutz, G. Decher, J.F. Nicoud, Philippe J.

Mésini

\section{- To cite this version:}

F.X. Simon, Th. Nguyen, M. Schmutz, G. Decher, J.F. Nicoud, et al.. Nitrochalcones as organogelators: evidence of the involvement of nitro groups and solvent in gel formation. New Journal of Chemistry, 2009, 33 (10), pp.2028-2033. 10.1039/b902444a . hal-00431723

\section{HAL Id: hal-00431723 \\ https://hal.science/hal-00431723}

Submitted on 9 Jan 2021

HAL is a multi-disciplinary open access archive for the deposit and dissemination of scientific research documents, whether they are published or not. The documents may come from teaching and research institutions in France or abroad, or from public or private research centers.
L'archive ouverte pluridisciplinaire HAL, est destinée au dépôt et à la diffusion de documents scientifiques de niveau recherche, publiés ou non, émanant des établissements d'enseignement et de recherche français ou étrangers, des laboratoires publics ou privés. 


\title{
Nitrochalcones as organogelators. Evidence of the involvement of nitro groups and solvent in gel formation
}

\author{
François-Xavier Simon, ${ }^{a}$ Thi-Thanh-Tam Nguyen, ${ }^{a}$ Marc Schmutz, ${ }^{a}$ Gero Decher, ${ }^{a}$ Jean-François \\ Nicoud ${ }^{* b}$ and Philippe J. Mésini ${ }^{* a}$
}

\section{${ }_{5}$ Received (in XXX, XXX) Xth XXXXXXXXX 200X, Accepted Xth XXXXXXXXX 200X First published on the web Xth $X X X X X X X X X 200 X$ DOI: $10.1039 / \mathbf{b 0 0 0 0 0 0 x}$}

New 4-alkoxynitrochalcones have been synthesized and been shown to be organogelators; the dodecyloxy derivative/benzyl alcohol gels has been studied by freeze fracture electron microscopy, ${ }_{10}$ DSC and FTIR. We show that the nitro group is involved in the formation of the gel and that the gelator co-assembles with solvent molecules.

\section{Introduction}

Low mass organogelators ${ }^{1-5}$ (LMOG) are a growing class of compounds able to form gels with organic solvents at low concentration (typically a few $\%$ per weight). This macroscopic property expresses the ability at the microscopic level to self-assemble into three dimensional fibrillar networks. Beside fundamental aspects, these gels receive an increasing attention due to their potential applications in nanotechnology, photovoltaics ${ }^{6}$ pollution control as oil spill recovery ${ }^{7}$ or toxics remediation devices,${ }^{8}$ biomedical field as scaffolds for tissue repair ${ }^{9,}{ }^{10}$ or drug-delivery systems, ${ }^{11,} 12$ mesoporous materials as templates for silica nanotubes ${ }^{13}$ or polymeric mesoporous materials. ${ }^{14-16}$

The self-association of gelators is achieved by a combination of non-covalent interactions including H-bonds, $\pi-\pi$ stacking, metal coordination and van der Waals interactions. Most of the known gelators possess H-bonding groups. The gelators able to self-assemble without H-bonds and only with weaker interactions are rare. Among them, one can find alkoxyaromatic ${ }^{17}, 18$ compounds, azobenzene derivatives, ${ }^{19}$ semifluoroalkanes ${ }^{20}$ and even simple alkanes. ${ }^{21}$ Ajayaghosh has extensively studied ${ }^{22}$ oligophenylvinylidene as gelators and has shown that these compounds form gels only if they have either H-bonding group such as alcohol or polar groups such as nitrile or nitro. Derivatives lacking these groups provided only limited aggregation. Herein we report the synthesis of new compounds based on the chalcone unit. Chalcone itself comprises two benzene rings linked together by a conjugated enone and does not show any aggregation itself. Herein we demonstrate that the introduction of a nitro group on one side and an alkoxy group on the opposite side leads to the aggregation of the resulting molecules in various solvents. We explored the structure of the formed gels by electron microscopy. FT-IR measurements have been performed to examine the role of the nitro group in the selfassociation of the gelator.

\section{Results and discussion}

New compounds incorporating the chalcone unit were synthesized (Scheme 1). $\mathrm{C}_{\mathrm{n}}-\mathrm{Ch}-\mathrm{NO}_{2}$ denotes 4'-alkoxy-4- nitrochalcones with different alkyl chain lengths (Scheme 1). For sake of comparison, compounds $\mathrm{O}_{2} \mathrm{~N}-\mathrm{Ch}-\mathrm{C}_{12}$, where the location of the nitro and alkyl groups are inverted, and di- $\mathrm{C}_{18}$ $\mathrm{Ch}-\mathrm{NO}_{2}$, that bears two side chains have also been synthesized.

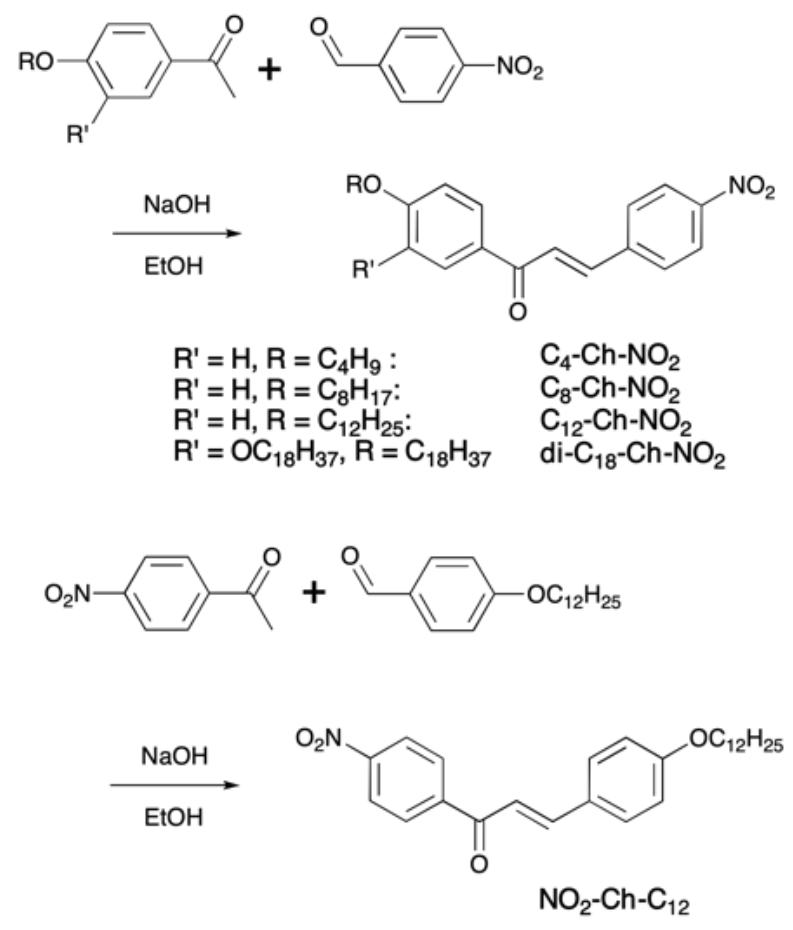

Scheme 1 Synthesis and structure of the studied compounds.

The synthesis, described in scheme 1, proceeds through the condensation of alkoxyacetophenone with 4nitrobenzaldehyde in ethanol $\left(\mathrm{C}_{\mathrm{n}}-\mathrm{Ch}-\mathrm{NO}_{2}\right)$ or the condensation of 4-nitroacetophenone with 4dodecyloxybenzaldehyde $\left(\mathrm{O}_{2} \mathrm{~N}-\mathrm{Ch}-\mathrm{C}_{12}\right)$, with $\mathrm{NaOH}$ as catalyst, according to a described method. ${ }^{23}$ The compounds were obtained pure with yield between 66 and $82 \%$. They all are solids at room temperature and are soluble in solvents such as $\mathrm{CH}_{2} \mathrm{Cl}_{2}, \mathrm{CHCl}_{3}$, toluene and EtOAc (table 1). In alcohols, the solubility properties depend on the alkyl chain length. In $\mathrm{MeOH} \mathrm{C}_{4}-\mathrm{Ch}-\mathrm{NO}_{2}$ forms a gel whereas longer chain analogues precipitate. In $\mathrm{BuOH}$, the trend is the 
opposite of the compounds $\mathrm{C}_{4}-\mathrm{Ch}-\mathrm{NO}_{2}$ and $\mathrm{C}_{8}-\mathrm{Ch}-\mathrm{NO}_{2}$ precipitate, whereas $\mathrm{C}_{12}-\mathrm{Ch}-\mathrm{NO}_{2}$ and di- $\mathrm{C}_{18}-\mathrm{Ch}-\mathrm{NO}_{2}$ form gels. In $\mathrm{BnOH}$, the $\mathrm{C} 4$ and $\mathrm{C} 8$ analogues are soluble, but longer chain analogues form gels. The reverse analogue $\mathrm{O}_{2} \mathrm{~N}-\mathrm{Ch}-\mathrm{C}_{12}$ differs from the other analogues since it precipitates in $\mathrm{BuOH}$ and is soluble in $\mathrm{BnOH}$. This result suggests that the orientation of the chalcone in respect with the alkyl chain is decisive in the packing of the molecules to form gels.

Table 1 Gelation properties of the nitrochalcone with various solvents. ${ }^{\text {a }}$

Solvent $\mathrm{C}_{4}-\mathrm{Ch}-\mathrm{NO}_{2} \mathrm{C}_{8}-\mathrm{Ch}-\mathrm{NO}_{2} \mathrm{C}_{12}-\mathrm{Ch}-\mathrm{NO}_{2} \mathrm{DiC}_{18}-\mathrm{Ch}-\mathrm{NO}_{2} \mathrm{O}_{2} \mathrm{~N}-\mathrm{Ch}-\mathrm{C}_{12}$

\begin{tabular}{cccccc}
\hline $\mathrm{C}_{6} \mathrm{H}_{6}$ & $\mathrm{P}$ & $\mathrm{P}$ & $\mathrm{P}$ & $\mathrm{P}$ & $/$ \\
$\mathrm{Et}_{2} \mathrm{O}$ & $\mathrm{P}$ & $\mathrm{S}$ & $\mathrm{G}(4)$ & $\mathrm{P}$ & $\mathrm{P}$ \\
$\mathrm{CCl}_{4}$ & $\mathrm{P}$ & $\mathrm{P}$ & $\mathrm{G}(2)$ & $\mathrm{P}$ & $\mathrm{P}$ \\
$\mathrm{CHCl}_{3}$ & $\mathrm{~S}$ & $\mathrm{~S}$ & $\mathrm{~S}$ & $\mathrm{~S}$ & $\mathrm{~S}$ \\
$\mathrm{CH}_{2} \mathrm{Cl}_{2}$ & $\mathrm{~S}$ & $\mathrm{~S}$ & $\mathrm{~S}$ & $\mathrm{P}$ & $/$ \\
$\mathrm{MeOH}$ & $\mathrm{G}(4)^{\mathrm{a}}$ & $\mathrm{P}$ & $\mathrm{P}$ & $\mathrm{I}$ & $\mathrm{P}$ \\
$\mathrm{BuOH}$ & $\mathrm{P}$ & $\mathrm{P}$ & $\mathrm{G}(2)$ & $\mathrm{G}(4)$ & $\mathrm{P}$ \\
$\mathrm{BnOH}$ & $\mathrm{S}$ & Visc. S & $\mathrm{G}(2)$ & $\mathrm{G}(2)$ & $\mathrm{S}$ \\
Toluene & $\mathrm{S}$ & $\mathrm{S}$ & $\mathrm{S}$ & $\mathrm{P}$ & $/$ \\
EtOAc & $\mathrm{S}$ & $\mathrm{S}$ & $\mathrm{S}$ & $\mathrm{S}$ & $/$ \\
nBuOAc & $\mathrm{S}$ & $\mathrm{S}$ & $\mathrm{G}(2)$ & $\mathrm{P}$ & $\mathrm{P}$ \\
${ }^{\mathrm{t} B u O A c}$ & $\mathrm{G}(4)$ & $\mathrm{G}(2)$ & $\mathrm{G}(2)$ & $\mathrm{P}$ & $\mathrm{P}$
\end{tabular}

${ }^{a}$ P precipitates; I insoluble in boiling solvent; G: gel (minimal gel concentration in wt \%); Visc. S : viscous solution. ${ }^{a}$ opaque gel

The structures of the gels have been explored by electron microscopy. Studies have been performed with freeze fracture. This technique consists in a rapid freeze of the gel, which preserves the self-assemblies in an amorphous solvent surrounding. This method which is well-known in aqueous media has been implemented successfully to organic solutions and gels and has proved to be efficient for the direct observation of self-assembled structures. ${ }^{16,24,25}$ The success of the technique depends on the ability of the solvent to remain amorphous when the sample is frozen; in our hands, only $\mathrm{BnOH}$ gave satisfactory results with the selected gelators. In the other systems, either the solvent crystallized during the freeze, which prevented the observation of structures, or the fracture planes displayed no objects.

For the gels from $\mathrm{C}_{12}-\mathrm{Ch}-\mathrm{NO}_{2}$ in $\mathrm{BnOH}$, the fractures show oblong structures (Fig. 1A, arrows). Higher magnifications (Fig. 1B) show that these objects are made from the assembly of fibrillar structures that are ordered into bundles. Solutions of the same compounds (conc. $1.9 \% \mathrm{wt}$ ) have been studied after deposition on carbon coated grids and rotary-shadowing (Fig. 1C). They show the same fibrils as in the gels, but less associated (arrows). The characteristic sizes of the structures have been measured both in gels and solutions on hundred of fibrils, and they were found to be identical in both states. The fibrils have a width of $25 \pm 3 \mathrm{~nm}$ and exhibit a periodical structure with alternate shadowed strips and clear ones (Fig. 1D). The widths of the shadowed ones are $10 \pm 2 \mathrm{~nm}$ and the periodic distance between two consecutive strips is $17 \pm 2 \mathrm{~nm}$. They form an angle of $50^{\circ}$ with the main axis of the fibers. In the gels, the ordered fibers are surrounded by disordered and shorter arrays (Fig. 1A and 1B, arrowhead). In close vicinity to the main bundles, these shorter structures are arranged parallel to the fibers, but the alignment decreases when their distance from the bundles increases.

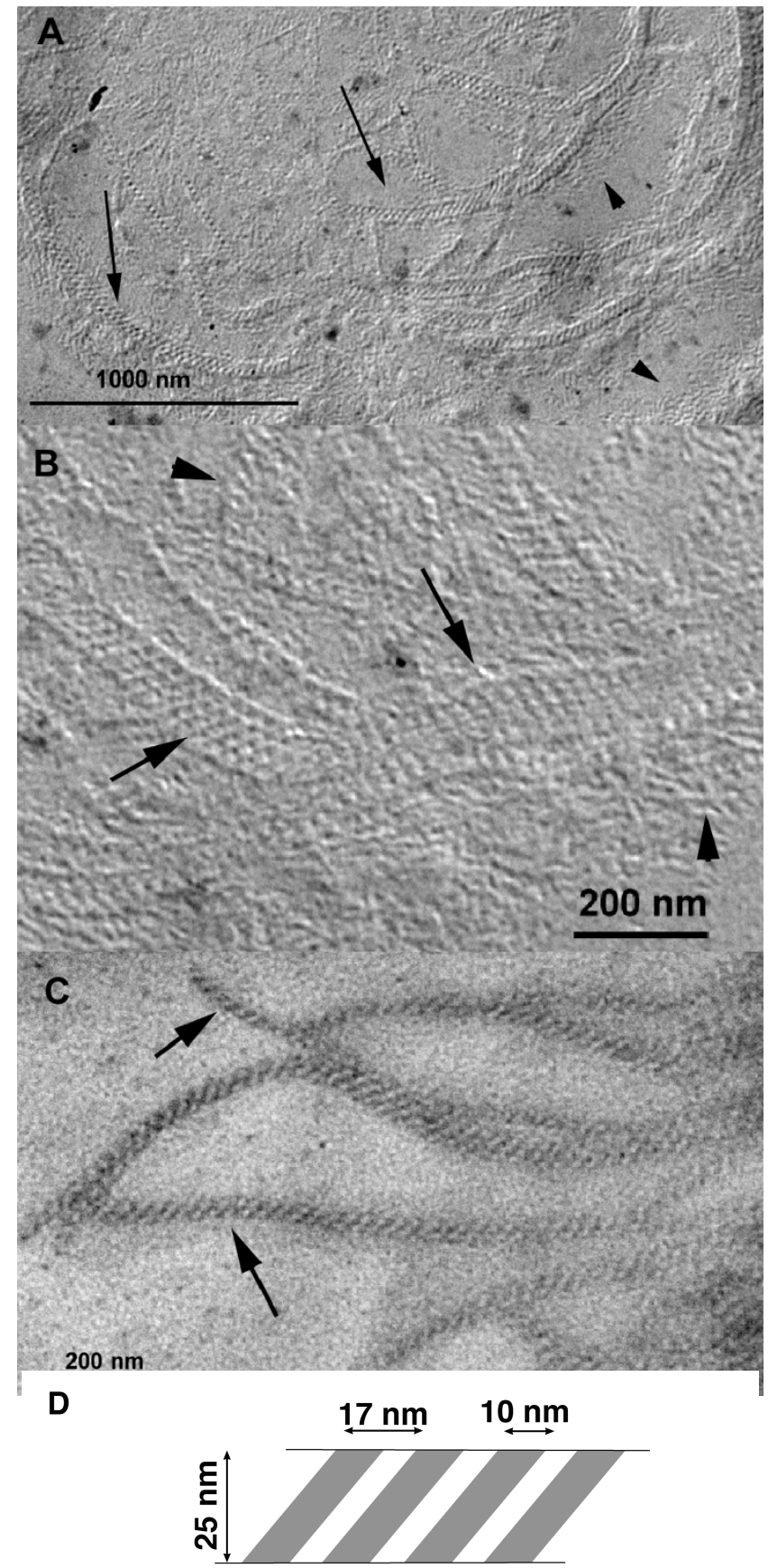

Fig. 1 A: TEM of $\mathrm{C}_{12}-\mathrm{Ch}-\mathrm{NO}_{2} / \mathrm{BnOH}$ gels $(2 \% \mathrm{wt})$ after freeze fracture. Arrows: periodical structures. Arrowhead: disordered structures. $\mathrm{B}$ : same objects with higher magnfication. C: TEM of solution of $\mathrm{C}_{12}-\mathrm{Ch}-$ $\mathrm{NO}_{2}$ in $\mathrm{BnOH}(1.9 \% \mathrm{wt})$ after adsorption on carbon grids; short arrow: single fibril; long arrow: double fibers. D : scheme of the characteristic distances measured in the fibers $( \pm 2 \mathrm{~nm})$.

The gel-to-sol transition was studied by DSC (Fig. 2). The thermograms clearly shows a first order and endothermic transition upon melting. The transition is very broad with an onset as low as $6^{\circ} \mathrm{C}$, and a maximum at $45^{\circ} \mathrm{C}$. The value of the enthalpy is found to be equal to $48 \mathrm{~kJ} \cdot \mathrm{mol}^{-1}$. When the mixture is cooled back down, a sharp exothermic transition is observed. Both endothermic and exothermic peaks yield the same absolute value of heat within $2 \%$ experimental 
uncertainty.

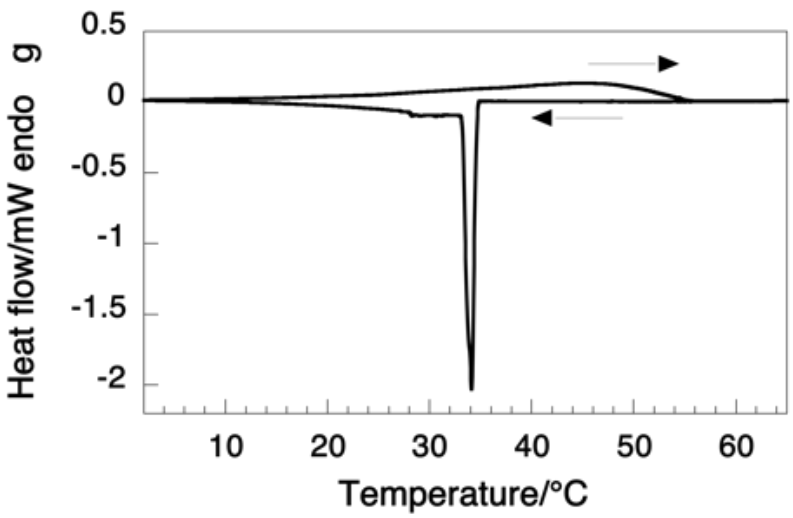

Fig. 2 Thermogram of $\mathrm{C}_{12}-\mathrm{Ch}-\mathrm{NO}_{2} / \mathrm{BnOH}$ gel $(2 \%$ wt.). The measured enthalpy for the gel-to-sol transition is $\Delta \mathrm{H}=48 \mathrm{~kJ} \cdot \mathrm{mol}^{-1}$.

The transition was studied by FTIR at different temperatures. Most of the bands of the spectra show little or no evolution. The strongest evolution is found for the bands between 1510 and $1540 \mathrm{~cm}^{-1}$. This signal comprises one peak at $1521 \mathrm{~cm}^{-1}$ and a set of two overlapping peaks at 1538 and $1534 \mathrm{~cm}^{-1}$.
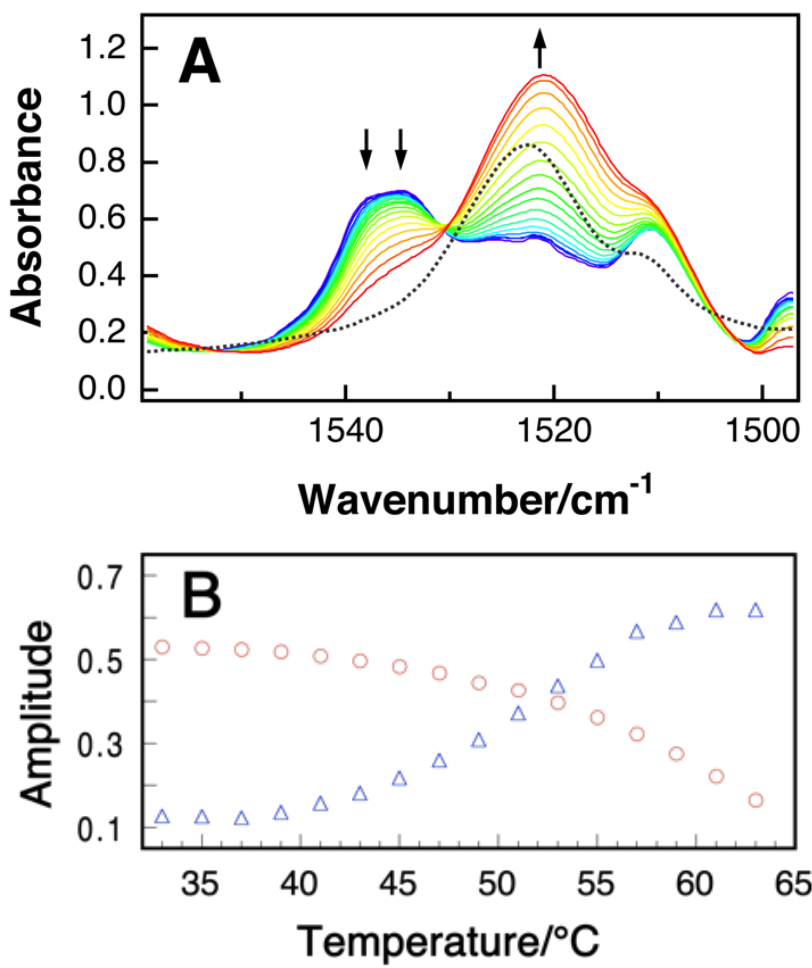

Fig. 3 FTIR of $\mathrm{C}_{12}-\mathrm{Ch}-\mathrm{NO}_{2} / \mathrm{BnOH}$ gel $\left(2 \%\right.$ wt.) in the $v_{\text {as }} \mathrm{NO}_{2}$ area, for temperatures varying from 32 to $65^{\circ} \mathrm{C}$ (plain lines); dotted line : $\mathrm{C}_{12}$-Ch$\mathrm{NO}_{2} / \mathrm{CHCl}_{3}$ solution. B : Amplitude of the bands at $1521 \mathrm{~cm}^{-1}(\mathrm{O})$ and sum of the amplitudes of the bands at 1334 and $1338 \mathrm{~cm}^{-1}(\triangle)$.

At lower temperature, the band at 1538 and at $1534 \mathrm{~cm}^{-1}$ are the dominant ones. When the temperature increases, their intensities decrease while the peak at $1521 \mathrm{~cm}^{-1}$ increases and becomes the major one at higher temperature. All the mentioned peaks can be assigned to the antisymmetric $\mathrm{NO}_{2}$ stretching $\left(v_{\text {as }} \mathrm{NO}_{2}\right){ }^{26}$ This strong change in the FTIR spectra during the transition shows that the $\mathrm{NO}_{2}$ group is involved in the self-assembly and the packing of the compound $\mathrm{C}_{12}-\mathrm{Ch}$ $\mathrm{NO}_{2}$ in gel formation. In chloroform, $\mathrm{C}_{12}-\mathrm{Ch}-\mathrm{NO}_{2}$ does not form any gel and the IR spectra are similar to the spectrum in $\mathrm{BnOH}$ at higher temperature: one observes only a major peak at $1523 \mathrm{~cm}^{-1}$ (Fig. 3A).

The evolution of the intensity at $1521 \mathrm{~cm}^{-1}$ in regard with temperature is very slow, and half of the maximal intensity is reached for $50{ }^{\circ} \mathrm{C}$ (Fig. 3B). For gels in tert-butyl acetate and $\mathrm{CCl}_{4}$ the same complex bands can be observed (Suppl. Info) in the $v_{\mathrm{s}} \mathrm{NO}_{2}$ area ('BuOAc: 1538, 1534 and $1526 \mathrm{~cm}^{-1}$; $\mathrm{CCl}_{4}: 1536$ and $\left.1526 \mathrm{~cm}^{-1}\right)$. The intensity band at $1526 \mathrm{~cm}^{-1}$ increases with increasing temperature like the band at 1521 $\mathrm{cm}^{-1}$ in $\mathrm{BnOH}$. For the neat solid, only the peak at 1536 is observed. These results show that splitting of the $v_{a s} \mathrm{NO}_{2}$ band is characteristic of the gel state. For the gels in $\mathrm{BnOH}$, the spectral region between 3700 and $3500 \mathrm{~cm}^{-1}$ exhibit two peaks after subtraction of the signal of the pure solvent. This spectral window does not comprise any bands of the gelator molecules and corresponds only to the $\mathrm{OH}$ stretching bands of the benzyl alcohol. In the gel state, these bands are clearly shifted toward higher frequencies than in the pure solvent (Fig. 4). Hence, for a small part of the benzyl alcohol molecules in the gel, the hydroxyl groups lead to H-bonds different from those existing the pure solvent. These bands also change when the gel melts, which shows the involvement of some $\mathrm{BnOH}$ molecules in the structure of the gel. It is possible that the hydroxyl interacts directly with the gelator either by an $\mathrm{H}$-bond with the nitro group as observed in solid state $^{27-29}$ or by the formation of a $\pi$-adduct between the $\mathrm{OH}$ and the gelator. ${ }^{30,} 31$ It is also possible that these $\mathrm{BnOH}$ molecules are associated with the gelators through van der Waals interactions and that this association results in looser $\mathrm{H}$-bonds with the rest of the solvent than in the bulk solvent.

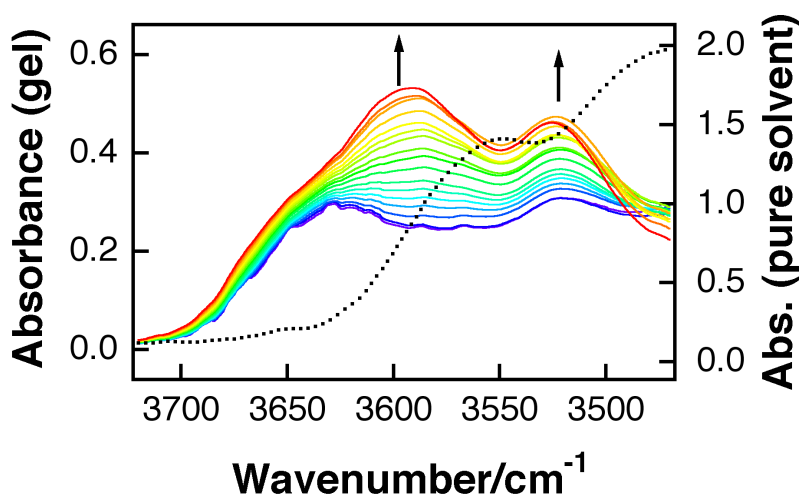

Fig. 4 Plain lines : FTIR of $\mathrm{C}_{12}-\mathrm{Ch}-\mathrm{NO}_{2} / \mathrm{BnOH}$ gel (2\% wt.) in the $\mathrm{OH}$ stretching area, for temperature varying from 32 to $65^{\circ} \mathrm{C}$. Dotted line :IR spectra of pure $\mathrm{BnOH}$.

The presence of isosbestic points proves that the system evolves through a two-state equilibrium, which corroborates the calorimetric data indicating that the transition is a first order one. The intensity of the peak at $1521 \mathrm{~cm}^{-1}$ evolves slowly over a large range of temperature, in the same way as the transition proceeds. The other bands in the spectra vary 
only slightly, which shows that the other parts of the molecule play only a minor role as compared to the nitro group. For instance, the symmetric vibration of the $\mathrm{CH}_{2}$ show a very weak increase from 2848 to $2849.5 \mathrm{~cm}^{-1}$ that parallels the evolution of the $\mathrm{NO}_{2}$ bands. The range of values indicates that the chains remain relatively well ordered and in an extended conformation in the sol phase.

\section{Conclusions}

New alkoxynitrochalcones were synthesized. These molecules are able to form gels in tert-butyl acetate at a few percent per weight. The dodecyl derivative is able to gel also $\mathrm{BuOH}$, $\mathrm{BnOH}$, ether and $\mathrm{CCl}_{4}$. The introduction of the polar nitro group into soluble chalcones transforms them into selfassociating compounds. Freeze fracture TEM allowed the visualization of the fibrillar structure formed by selfassociation. FTIR study in this solvent confirmed the strong implication of the nitro group in the formation of the gel. The same studies also showed the involvement of solvent molecules in the structure of the gel. This phenomenon has been very rarely observed in organogels. It can be considered as an extension of the case of two component gelators ${ }^{32}$ such as AOT/phenol. ${ }^{32-35}$ In those cases, a mixture of two molecules is required to form the gel. Therefore despite their modest gel concentration, this new family of gelators has an original structure. Further structural studies are in progress to gain new insights into these self-assemblies and to increase their gelation abilities.

\section{Experimental}

FTIR. Spectra were recorded on a Bruker Vertex 70 spectrophotometer equipped with a thermostatic cell holder and a temperature-controlling unit (Specac West 6100+). The gels were placed in a $\mathrm{NaCl}$ cell with an optical path of 0.1 $\mathrm{mm}$. The samples were visually checked after a heating period to ensure that no loss of solvent occurred. The curves were processed and fitted in Igor (Wavemetrics, Inc.). The complex signals were deconvoluted as follows: the maxima of the peaks were found with the second or forth derivatives of the spectra. Amplitudes and width of the peaks were fitted with Gaussian curves with the Igor built-in algorithm.

DSC. Thermograms were recorded with a microcalorimeter DSC III from Setaram. A first heating cycle was performed between 6 and $85{ }^{\circ} \mathrm{C}$ at a rate of $1{ }^{\circ} \mathrm{C} / \mathrm{min}$. The heat was measured in second and third scan at a rate of $0.1{ }^{\circ} \mathrm{C} / \mathrm{min}$. No difference was observed between the second and third scan.

Freeze-fracture electron microscopy. Transmission electron microscopy (TEM) was performed with a Philips CM12 microscope operating at $120 \mathrm{kV}$. The gel samples were placed between two copper holders and rapidly frozen in liquid nitrogen. The sample was kept frozen and transferred into a freeze-fracture apparatus (developed by Dr. J.-C. Homo) where the sample was cleaved. Pt was evaporated onto the sample under $45^{\circ}$ angle, and then carbon under a $90^{\circ}$ angle respective to the surface. The sample was warmed to room temperature, and the replica was rinsed with chloroform and deposited on 400 mesh grids
Synthesis. The compounds were synthesized by the method of Murphy; ${ }^{23}$ the typical procedure is described for the exemple below.

4'-Dodecyloxy-4-nitrochalcone $\quad\left(\mathrm{C}_{12}-\mathrm{Ch}-\mathrm{NO}_{2}\right): \quad 4-$ nitrobenzaldehyde $(100.2 \mathrm{mg}, \quad 0.66 \mathrm{mmol})$ and 4dodecyloxyacetophenone (201.6 mg, $0.66 \mathrm{mmol}, 1$ equiv.) were added to a solution of $\mathrm{NaOH}$ in $\mathrm{EtOH}(0.1 \mathrm{M}, 10 \mathrm{~mL})$. The reaction mixture was stirred at $25{ }^{\circ} \mathrm{C}$ for $24 \mathrm{~h}$. Water $(150$ $\mathrm{mL}$ ) was added and the resulting precipitate was separated with centrifugation, and re-suspended in fresh water and centrifuged twice. The dried precipitate was recrystallized from cyclohexane to yield the pure compound as a yellow powder (191 mg, $66 \%$ yield). M. p. $103.5{ }^{\circ} \mathrm{C}$. Found: C, 73.88; H, 8.30; N, 3.22. Calc. For $\mathrm{C}_{27} \mathrm{H}_{35} \mathrm{NO}_{4}$ : C, 74.11; $\mathrm{H}$, 8.06; N, 3.20\%). $\delta_{\mathrm{H}}\left(400 \mathrm{Mhz}, \mathrm{CDCl}_{3}\right): 8.28\left(2 \mathrm{H}, \mathrm{d}, \mathrm{ArNO}_{2}\right.$ $\mathrm{C} 3-\mathrm{H}), 8.04$ (2H, d, $J$ 8.9, $\left.\mathrm{ArNO}_{2} \mathrm{C} 2-\mathrm{H}\right), 7.83-7.77$ (3H, m, $\mathrm{CH}=\mathrm{CH}-\mathrm{CO}$ and ArOR C2-H), $7.66(1 \mathrm{H}, \mathrm{d}, J 15.7, \mathrm{CH}=\mathrm{CH}-$ $\mathrm{CO})$, 7.00-6.98 (2H, m, ArOR C4H), $4.05(2 \mathrm{H}, \mathrm{t}, J$ 6.5, $\left.\mathrm{ArOCH}_{2}\right), 1.82\left(2 \mathrm{H}, \mathrm{p}, J\right.$ 7.0, $\left.\mathrm{ArOCH}_{2} \mathrm{CH}_{2}\right), 1.48(2 \mathrm{H}, \mathrm{p}, J$ 7.0, $\left.\mathrm{ArOCH}_{2} \mathrm{CH}_{2} \mathrm{CH}_{2}\right), 1.38-1.24\left(16 \mathrm{H}, \mathrm{m}, \mathrm{CH}_{2}\right), 0.88(3 \mathrm{H}, \mathrm{t}$, $J$ 7.0, $\left.\mathrm{CH}_{3}\right) . \delta_{\mathrm{C}}\left(100 \mathrm{Mhz}, \mathrm{CDCl}_{3}\right): 187.7(\mathrm{CO}), 163.5(\mathrm{C} 4-\mathrm{O})$, $148.4\left(\mathrm{C}-\mathrm{NO}_{2}\right), 141.3(\mathrm{C}=\mathrm{C}-\mathrm{CO}), 140.5\left(\mathrm{C} 1-\mathrm{ArNO}_{2}\right), 131.0$ 130.2 (C1 ArOR), $128.8\left(\mathrm{C} 2-\mathrm{ArNO}_{2}\right), 125.7(\mathrm{CO}-\mathrm{CH}=\mathrm{CH})$, $124.2\left(\mathrm{C} 2-\mathrm{ArNO}_{2}\right), 114.5(\mathrm{C} 3-\mathrm{ArOR}), 68.4\left(\mathrm{ArOCH}_{2}\right), 31.9$ $\left(\mathrm{CH}_{2} \mathrm{CH}_{2} \mathrm{CH}_{3}\right), 29.63,29.60,29.56,29.53,29.32,29.1,26.0$ $\left(\mathrm{ArOCH}_{2} \mathrm{CH}_{2} \mathrm{CH}_{2}\right), \quad 22.7 \quad\left(\mathrm{CH}_{2} \mathrm{CH}_{3}\right), \quad 14.1 \quad\left(\mathrm{CH}_{3}\right) . \quad \lambda_{\max }$ $\left(\mathrm{CHCl}_{3}\right) / \mathrm{nm} 314\left(\varepsilon / \mathrm{dm}^{3} \mathrm{~mol}^{-1} \mathrm{~cm}^{-1} 12\right.$ 900). $v / \mathrm{cm}-1$ (gel in $\mathrm{BnOH})$ 2957, 2939, 2939, 2918, 2947, 1656 (v CO), 1610, $1600,1538\left(v_{\mathrm{as}} \mathrm{NO}_{2}\right), 1534\left(v_{\mathrm{as}} \mathrm{NO}_{2}\right), 1521\left(v_{\mathrm{s}} \mathrm{NO}_{2}\right), 1344$, $1320\left(v_{\mathrm{s}} \mathrm{NO}_{2}\right), 1310\left(v_{\mathrm{s}} \mathrm{NO}_{2}\right), 1262,1225,1179,855,831$, 816.

4'-Butyloxy-4-nitrochalcone $\left(\mathrm{C}_{4}-\mathrm{Ch}_{-} \mathrm{NO}_{2}\right):$ M. p. 125 ${ }^{\circ} \mathrm{C}$; Found: C, 69.95; H, 6.05; N, 4.12. (Calc. For $\mathrm{C}_{19} \mathrm{H}_{19} \mathrm{NO}_{4}$ : $\mathrm{C}, 70.14 ; \mathrm{H}, 5.89 ; \mathrm{N}, 4.31 \%) ; \delta_{\mathrm{H}}\left(400 \mathrm{Mhz}, \mathrm{CDCl}_{3}\right): 8.29(2 \mathrm{H}$, d, $J$ 8.2, $\left.\mathrm{ArNO}_{2} \mathrm{C} 3-\mathrm{H}\right), 8.06\left(2 \mathrm{H}, \mathrm{d}, J\right.$ 8.4, $\left.\mathrm{ArNO}_{2} \mathrm{C} 2-\mathrm{H}\right)$, 7.84-7.79 $(3 \mathrm{H}, \mathrm{m}, \mathrm{CH}=\mathrm{CH}-\mathrm{CO}$ and ArOR C2-H), $7.67(1 \mathrm{H}, \mathrm{d}$, $J$ 15.5, $\mathrm{CH}=\mathrm{CH}-\mathrm{CO}), 7.02(2 \mathrm{H}, \mathrm{d}, 8.5, \operatorname{ArOR} \mathrm{C} 4 H), 4.08(2 \mathrm{H}$, $\left.\mathrm{t}, J 6.6, \mathrm{ArOCH}_{2}\right), 1.83\left(2 \mathrm{H}, \mathrm{p}, J 6.6, \mathrm{ArOCH}_{2} \mathrm{CH}_{2}\right), 1.55(2 \mathrm{H}$, $\left.\mathrm{m}, \mathrm{ArOCH}_{2} \mathrm{CH}_{2} \mathrm{CH}_{2}\right), 0.88\left(3 \mathrm{H}, \mathrm{t}, J 7.2, \mathrm{CH}_{3}\right) . \delta_{\mathrm{C}}(100 \mathrm{Mhz}$, $\left.\mathrm{CDCl}_{3}\right)$ : 187.7 (CO), $163.6(\mathrm{C} 4-\mathrm{O}), 148.4\left(\mathrm{C}-\mathrm{NO}_{2}\right), 141.3$ $(\mathrm{CH}=\mathrm{CH}-\mathrm{CO}), 140.5\left(\mathrm{ArNO}_{2} \mathrm{C} 1\right), 131.2$ (C2 ArOR), 130.2 (C1 ArOR), 128.8 (ArOR C2), $125.7(\mathrm{CH}=\mathrm{CH}-\mathrm{CO}), 124.2$ $\left(\begin{array}{lllll}\mathrm{ArNO}_{2} & \mathrm{C} 3\end{array}\right), 114.5$ (C3-ArOR), $68.1 \quad\left(\mathrm{ArOCH}_{2}\right), 31.1$ $\left(\mathrm{CH}_{2} \mathrm{CH}_{2} \mathrm{CH}_{3}\right), 19.2\left(\mathrm{CH}_{2} \mathrm{CH}_{3}\right), 14.1\left(\mathrm{CH}_{3}\right) . \mathrm{v} / \mathrm{cm}^{-1}$ (ATR) 3079.4, 1657 (vCO), 1607, 1598, 1586, 1510 (s, vas $\mathrm{NO}_{2}$ ), 1473, $1339\left(\mathrm{~s}, v_{\mathrm{s}} \mathrm{NO}_{2}\right), 1228,1123,1169(\mathrm{~s}, v \mathrm{CN}), 1000$, $833,825,760$.

4'-Octyloxy-4-nitrochalcone $\quad\left(\mathbf{C}_{8}-\mathbf{C h}-\mathbf{N O}_{2}\right):$ M. p. 106 ${ }^{\circ} \mathrm{C}$; Found: C, 72.22; H, 7.31; N, 3.82. Calc. For $\mathrm{C}_{27} \mathrm{H}_{35} \mathrm{NO}_{4}$ : $\mathrm{C}, 72.42 ; \mathrm{H}, 7.13 ; \mathrm{N}, 3.67 \% ; \delta_{\mathrm{H}}\left(400 \mathrm{Mhz}, \mathrm{CDCl}_{3}\right): 8.27(2 \mathrm{H}$, d, $J$ 8.53, $\left.\mathrm{ArNO}_{2} \mathrm{C} 3-\mathrm{H}, \mathrm{C} 5-\mathrm{H}\right), 8.03\left(2 \mathrm{H}, \mathrm{d}, J 8.7, \mathrm{ArNO}_{2} \mathrm{C} 2-\right.$ $\mathrm{H}$ and $\mathrm{C} 6-\mathrm{H}), 7.82-7.79(3 \mathrm{H}, \mathrm{m}, \mathrm{CH}=\mathrm{CH}-\mathrm{CO}$ and ArOR C2- $\mathrm{H}$ $\mathrm{C} 6-H), 7.65(1 \mathrm{H}, \mathrm{d}, J 15.7, \mathrm{CH}=\mathrm{CH}-\mathrm{CO}), 6.99(2 \mathrm{H}, \mathrm{d}, J$ 8.7, ArOR C3'-H and C5'-H), 4.04 (2H, t, $J$ 6.3, ArOCH$\left._{2}\right), 1.82$ $\left(2 \mathrm{H}, \mathrm{p}, J\right.$ 6.6, $\left.\mathrm{ArOCH}_{2} \mathrm{CH}_{2}\right), 1.59\left(2 \mathrm{H}, \mathrm{m}, \mathrm{ArOCH}_{2} \mathrm{CH}_{2} \mathrm{CH}_{2}\right)$, 1,47-1,20 (8 H, CH $), 0.89\left(3 \mathrm{H}, \mathrm{t}, J\right.$ 7.2, $\left.\mathrm{CH}_{3}\right) . \delta_{\mathrm{C}}(100 \mathrm{Mhz}$, $\left.\mathrm{CDCl}_{3}\right): 188.1(\mathrm{CO}), 163.9(\mathrm{C} 4-\mathrm{O}), 148.8\left(\mathrm{C}-\mathrm{NO}_{2}\right), 141.7$ $(\mathrm{CH}=\mathrm{CH}-\mathrm{CO}), 140.9\left(\mathrm{ArNO}_{2} \mathrm{C} 1\right), 131.3\left(\mathrm{ArOR} \mathrm{C}^{\prime}\right), 130.6$ 
(C1' ArOR), $129.2\left(\mathrm{ArNO}_{2} \mathrm{C} 2\right.$ and $\left.\mathrm{C} 6\right), 126.0(\mathrm{CH}=\mathrm{CH}-\mathrm{CO})$, $124.5\left(\mathrm{ArNO}_{2} \mathrm{C} 3\right.$ and $\left.\mathrm{C} 5\right), 114.8$ (ArOR C3' and $\left.\mathrm{C}^{\prime}\right), 68.7$ $\left(\mathrm{ArOCH} \mathrm{H}_{2}\right), 32.1\left(\mathrm{CH}_{2} \mathrm{CH}_{2} \mathrm{CH}_{3}\right), 29.7\left(\mathrm{ArOCH}_{2} \mathrm{CH}_{2}\right), 29.5$ $\left(\mathrm{ArO}\left(\mathrm{CH}_{2}\right)_{3} \mathrm{CH}_{2}\right), \quad 29.4 \quad\left(\mathrm{ArO}\left(\mathrm{CH}_{2}\right)_{4} \boldsymbol{C H}_{2}\right), \quad 26.3$ $\left(\mathrm{ArO}\left(\mathrm{CH}_{2}\right)_{2} \mathrm{CH}_{2}\right), 23.0\left(\mathrm{CH}_{2} \mathrm{CH}_{3}\right), 14.4\left(\mathrm{CH}_{3}\right) . \mathrm{v} / \mathrm{cm}^{-1}$ (ATR) $2955\left(v_{\mathrm{as}} \mathrm{CH}_{3}\right), 2919\left(v_{\mathrm{as}} \mathrm{CH}_{2}\right), 2874\left(v_{\mathrm{s}} \mathrm{CH}_{3}\right), 2850\left(v_{\mathrm{s}}\right.$ $\left.\mathrm{CH}_{2}\right), 1656$ ( $\left.v \mathrm{CO}\right), 1610\left(\mathrm{VCC}_{\mathrm{Ar}}\right), 1593(\mathrm{vC}=\mathrm{C}$ (enone)), $1534\left(\mathrm{~s}, v_{\mathrm{as}} \mathrm{NO}_{2}\right), 1511,1467,1342\left(\mathrm{~s}, \mathrm{v}_{\mathrm{s}} \mathrm{NO}_{2}\right), 1259$ (s, vas, =C-O-C), 1221, $1178(\mathrm{~s}, v \mathrm{CN}), 1070\left(\mathrm{~s}, \mathrm{v}_{\mathrm{s}},=\mathrm{C}-\mathrm{O}\right), 1033$, 988 (C-N stretching), 980, 780, 760, 733, 655, 631.

3',4'-Dioctadecyloxy-4-nitrochalcone (di-C $\left.\mathbf{1 8}_{\mathbf{8}}-\mathbf{C h}-\mathrm{NO}_{\mathbf{2}}\right)$ : M. p. $120{ }^{\circ} \mathrm{C}$; Found: C, 77.38; H, 10.74; N, 1.85. Calc. For $\mathrm{C}_{27} \mathrm{H}_{35} \mathrm{NO}_{4}: \mathrm{C}, 77.52 ; \mathrm{H}, 10.59 ; \mathrm{N}, 1.77 \% ; \delta_{\mathrm{H}}(400 \mathrm{Mhz}$, $\left.\mathrm{CDCl}_{3}\right): 8.27\left(2 \mathrm{H}, \mathrm{d}, J\right.$ 8.72, $\left.\mathrm{ArNO}_{2} \mathrm{C} 3-\mathrm{H}\right), 7.82-7.77(3 \mathrm{H}$, $\mathrm{m}, \mathrm{ArNO}_{2} \mathrm{C} 2-\mathrm{H}$ and $\left.\mathrm{CH}=\mathrm{CH}-\mathrm{CO}\right), 7.67-7.61(3 \mathrm{H}, \mathrm{m}, \mathrm{ArOR}$ $\mathrm{C} 6-H$ and, $\mathrm{CH}=\mathrm{C} H-\mathrm{CO}), 6.92(1 \mathrm{H}, \mathrm{d}, J$ 8.52, ArOR C5-H), $4.09\left(4 \mathrm{H}, \mathrm{t}, J\right.$ 6.48, $\left.\mathrm{ArOCH}_{2}\right), 1.86(4 \mathrm{H}, \mathrm{p}, J$ 6.48, $\left.\mathrm{ArOCH}_{2} \mathrm{CH}_{2}\right), 1.57\left(4 \mathrm{H}, \mathrm{m}, \mathrm{ArOCH}_{2} \mathrm{CH}_{2} \mathrm{CH}_{2}\right), 1.48(4 \mathrm{H}, \mathrm{m}$, $\left.\mathrm{CH}_{2} \mathrm{CH}_{3}\right), 1.25\left(52 \mathrm{H}, \mathrm{CH}_{2}\right), 0.88\left(6 \mathrm{H}, \mathrm{t}, J 7.0, \mathrm{CH}_{3}\right) . \delta_{\mathrm{C}}(100$ $\left.\mathrm{Mhz}, \mathrm{CDCl}_{3}\right)$ : 188.1 (CO), 154.4 (C4-OR), $149.7\left(\mathrm{C}-\mathrm{NO}_{2}\right)$, $148.8(\mathrm{CH}=\mathrm{CH}-\mathrm{CO}), 140.8\left(\mathrm{ArNO}_{2} \mathrm{C} 1\right), 130.8(\mathrm{C} 1 \mathrm{ArOR})$, $129.2\left(\mathrm{C} 2 \mathrm{ArNO}_{2}\right), 126.0(\mathrm{CH}=\mathrm{CH}-\mathrm{CO}), 124.5\left(\mathrm{ArNO}_{2} \mathrm{C} 3\right)$, 123.7 (C6 ArOR), 113.3 (C2 ArOR), 111.9 (C5 ArOR), 69.7 (ArOCH2-R'), 69.5 (ArOCH2-R), $32.3\left(\mathrm{CH}_{2} \mathrm{CH}_{2} \mathrm{CH}_{3}\right), 27.3$ $\left(\mathrm{ArOCH} \mathrm{CH}_{2} \mathrm{CH}_{2}\right), 23.0\left(\mathrm{CH}_{2} \mathrm{CH}_{3}\right), 14.5\left(\mathrm{CH}_{3}\right) . v / \mathrm{cm}^{-1}$ (ATR) $2956\left(v_{\text {as }} \mathrm{CH}_{3}\right), 2916\left(v_{\mathrm{as}} \mathrm{CH}_{2}\right), 2873\left(v_{\mathrm{s}} \mathrm{CH}_{3}\right), 2849\left(v_{\mathrm{s}} \mathrm{CH}_{2}\right)$, 1655 ( $v \mathrm{CO}), 1578\left(\mathrm{vC}=\mathrm{C}\right.$ (enone)), $1525\left(\mathrm{~s}, \mathrm{v}_{\mathrm{as}} \mathrm{NO}_{2}\right), 1514$, 1467, 1434 ( $\delta \mathrm{CH}$ vinyle), $1343\left(\mathrm{~s}, \mathrm{v}_{\mathrm{s}} \mathrm{NO}_{2}\right), 1278,1267(\mathrm{~s}$, $\left.v_{\mathrm{as}},=\mathrm{C}-\mathrm{O}-\mathrm{C}\right), 1217,1177,1153(\mathrm{~s}, v \mathrm{CN}), 1069\left(\mathrm{~s}, \mathrm{v}_{\mathrm{s}},=\mathrm{C}-\mathrm{O}\right)$, 995 (C-N stretching), 840, 813, 754, 721, 675, 630.

4-Dodecyloxy-4'-nitrochalcone $\left(\mathbf{O}_{\mathbf{2}} \mathbf{N}-\mathbf{C h}-\mathbf{C}_{12}\right):$ M. p. 108 ${ }^{\circ} \mathrm{C}$; Found: $\mathrm{C}, 73.92 ; \mathrm{H}, 8.24 ; \mathrm{N}, 3.25$. Calc. For $\mathrm{C}_{27} \mathrm{H}_{35} \mathrm{NO}_{4}$ : $\mathrm{C}, 74.11 ; \mathrm{H}, 8.06 ; \mathrm{N}, 3.20 \% ; \delta_{\mathrm{H}}\left(400 \mathrm{Mhz}, \mathrm{CDCl}_{3}\right): 8.34(2 \mathrm{H}$, $\mathrm{d}, J$ 8.4, $\mathrm{ArNO}_{2} \mathrm{C} 3-\mathrm{H}$ and $\left.\mathrm{C} 5-\mathrm{H}\right), 8.12\left(2 \mathrm{H}, \mathrm{d}, J 8.2, \mathrm{ArNO}_{2}\right.$ $\mathrm{C} 2-\mathrm{H}$ and C6-H), $7.81(1 \mathrm{H}, \mathrm{d}, J$ 15.2, $\mathrm{CH}=\mathrm{CH}-\mathrm{CO}), 7.60(2 \mathrm{H}$, $\mathrm{d}, J$ 8.4, ArOR C2-H and C6-H), $7.35(1 \mathrm{H}, \mathrm{d}, J 15.4, \mathrm{CH}=\mathrm{CH}-$ $\mathrm{CO}), 6.94$ (2H, d, $J$ 8.0, ArOR C3-H and C5-H), $4.02(2 \mathrm{H}, \mathrm{t}, J$ 6.3, $\left.\mathrm{ArOCH}_{2}\right), 1.81\left(2 \mathrm{H}, \mathrm{p}, J\right.$ 6.6, $\left.\mathrm{ArOCH}_{2} \mathrm{CH}_{2}\right), 1.54-1.21$ (18 $\left.\mathrm{H}, \mathrm{CH}_{2}\right), 0.89\left(3 \mathrm{H}, \mathrm{t}, J\right.$ 7.2, $\left.\mathrm{CH}_{3}\right) . \delta_{\mathrm{C}}\left(100 \mathrm{Mhz}, \mathrm{CDCl}_{3}\right)$ :

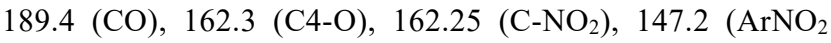
$\mathrm{C} 1), 143.9(\mathrm{CH}=\mathrm{CH}-\mathrm{CO}), 131.0\left(\mathrm{ArNO}_{2} \mathrm{C} 2\right), 129.7$ (ArOR $\mathrm{C} 2$ and $\mathrm{C} 6), 127.1$ (C1 ArOR), $124.2\left(\mathrm{ArNO}_{2} \mathrm{C} 3\right.$ and $\left.\mathrm{C} 5\right)$, $119.1 \quad(\mathrm{CH}=\mathrm{CH}-\mathrm{CO}), \quad 115.4$ (ArOR $\mathrm{C} 5$ and $\mathrm{C} 3), 68.7$ $\left.(\mathrm{ArOCH})_{2}\right), 32.3\left(\mathrm{CH}_{2} \mathrm{CH}_{2} \mathrm{CH}_{3}\right), 26.3\left(\mathrm{ArOCH}_{2} \mathrm{CH}_{2} \mathrm{CH}_{2}\right), 23.0$ $\left(\mathrm{CH}_{2} \mathrm{CH}_{3}\right), 14.5\left(\mathrm{CH}_{3}\right) . v / \mathrm{cm}^{-1}$ (ATR) $2946\left(v_{\mathrm{as}} \mathrm{CH}_{3}\right), 2916$ $\left(v_{\mathrm{as}} \mathrm{CH}_{2}\right), 2871\left(v_{\mathrm{s}} \mathrm{CH}_{3}\right), 2849\left(v_{\mathrm{s}} \mathrm{CH}_{2}\right), 1657$ ( $\left.v \mathrm{CO}\right), 1587$ $(v \mathrm{C}=\mathrm{C}$ (enone) $), 1567,1512\left(\mathrm{~s}, \mathrm{v}_{\mathrm{as}} \mathrm{NO}_{2}\right), 1476,1463,1425$, $1340\left(\mathrm{~s}, \mathrm{v}_{\mathrm{s}} \mathrm{NO}_{2}\right), 1295,1256\left(\mathrm{~s}, \mathrm{v}_{\mathrm{as}},=\mathrm{C}-\mathrm{O}-\mathrm{C}\right), 1217,1173(\mathrm{~s}$, $v \mathrm{CN}), 1061\left(\mathrm{~s}, v_{\mathrm{s}},=\mathrm{C}-\mathrm{O}\right), 989(\mathrm{C}-\mathrm{N}$ stretching), 832, 826, $767,727,703,638$.

\section{Notes and references}

${ }^{a}$ Institut Charles Sadron, CNRS, 23 rue du Loess, BP 84047, 67034 Strasbourg Cedex 2, France. Fax: 33 (0)388 4140 99; Tel: 33 (0)388 41 40 70; E-mail: mesini@ics.u-strasbg.fr

${ }^{b}$ Laboratoire de Biophotonique et Pharmacologie, CNRS UMR 7213, Faculté de Pharmacie, 74 route du Rhin BP 60024, 67401 Illkirch Cedex, France. Tel: 33 (0)390 2442 76; E-mail:

Jean-Francois.Nicoud@pharma.u-strasbg.fr $\dagger$ Electronic Supplementary Information (ESI) available: FTIR spectra of $\mathrm{C}_{12}-\mathrm{Ch}-\mathrm{NO}_{2}$ gels in tert-butyl acetate and $\mathrm{CCl}_{4}$ and $\mathrm{C}_{12}-\mathrm{Ch}-\mathrm{NO}_{2}$ solid. See DOI: $10.1039 / \mathrm{b} 000000 \mathrm{x} /$

1. P. Terech and R. G. Weiss, Chem. Rev., 1997, 97, 3133-3159.

2. J. H. Van Esch and B. L. Feringa, Angew. Chem., Int. Ed. Engl., 2000, 39, 2263-2266.

3. L. A. Estroff and A. D. Hamilton, Chem. Rev., 2004, 104, 1201-1218.

4. N. M. Sangeetha and U. Maitra, Chem. Soc. Rev., 2005, 34, 821-836.

5. R. G. Weiss and P. Terech, Molecular gels. Materials with selfassembled Fibrillar Network, Springer, Dordrecht, The Netherlands, 2006.

6. W. Kubo, K. Murakoshi, T. Kitamura, S. Yoshida, M. Haruki, K. Hanabusa, H. Shirai, Y. Wada and S. Yanagida, J. Phys. Chem. B, 2001, 105, 12809-12815.

7. S. Bhattacharya and Y. Krishnan Ghosh, Chem. Commun., 2001, $185-186$

8. S. Kiyonaka, K. Sugiyasu, S. Shinkai and I. Hamachi, J. Am. Chem. Soc., 2002, 124, 10954-10955.

9. T. C. Holmes, S. de Lacalle, X. Su, G. Liu, A. Rich and S. Zhang, Proc. Natl. Acad. Sci. USA, 2000, 97, 6728-6733.

10. R. G. Ellis-Behnke, Y.-X. Liang, S.-W. You, D. K. C. Tay, S. Zhang, K.-F. So and G. E. Schneider, Proc. Natl. Acad. Sci. USA, 2006, 103, 5054-5059.

11. S. Murdan, T. Andrysek and D. Son, Int J Pharm, 2005, 300, $113-$ 124.

12. S. Murdan, Expert Opin. Drug Deliv., 2005, 2, 489-505.

13. K. J. C. van Bommel, A. Friggeri and S. Shinkai, Angew. Chem., Int. Ed. Engl., 2003, 42, 980-999.

14. R. J. H. Hafkamp, B. P. A. Kokke, I. M. Danke, H. P. M. Geurts, A. E. Rowan, M. C. Feiters and R. J. M. Nolte, Chem. Commun., 1997, 545-546.

15. G. Tan, M. Singh, J. He, V. T. John and G. L. McPherson, Langmuir, 2005, 21, 9322-9326.

16. F. X. Simon, N. S. Khelfallah, M. Schmutz, N. Diaz and P. J. Mesini, J. Am. Chem. Soc., 2007, 129, 3788-3789.

17. T. Brotin, R. Utermohlen, F. Fages, H. Bouas-Laurent and J. P. Desvergne, J. Chem. Soc., Chem. Commun., 1991, 416-418.

18. F. Placin, M. Colomes and J.-P. Desvergne, Tetrahedron Lett., 1997, 38, 2665-2668.

19. J.-i. Mamiya, K. Kanie, T. Hiyama, T. Ikeda and T. Kato, Chem. Commun., 2002, 1870-1871.

20. R. J. Twieg, T. P. Russell, R. Siemens and J. F. Rabolt, Macromolecules, 1985, 18, 1361-1362.

21. D. J. Abdallah and R. G. Weiss, Langmuir, 2000, 16, 352-355.

22. A. Ajayaghosh and V. K. Praveen, Acc. Chem. Res., 2007, 40, 644656.

23. S. Wattanasin and W. S. Murphy, Synthesis, 1980, 647-650.

24. N. Diaz, F. X. Simon, M. Schmutz, M. Rawiso, G. Decher, J. Jestin and P. J. Mésini, Angew. Chem., Int. Ed. Engl., 2005, 44, 3260-3264.

25. R. Schmidt, F. B. Adam, M. Michel, M. Schmutz, G. Decher and P. J. Mésini, Tetrahedron Lett., 2003, 44, 3171-3174.

26. J. F. Brown, J. Am. Chem. Soc., 1955, 77, 6341-6351.

27. M. Harrand, J. Raman Spectrosc., 1975, 4, 53-73.

28. M. Harrand, J. Raman Spectrosc., 1979, 8, 161-164.

29. D. Graham, A. R. Kennedy, C. J. McHugh, W. E. Smith, W. I. F. David, K. Shankland and N. Shankland, New J. Chem., 2004, 28, 161-165.

30. M. R. Basila, E. L. Saier and L. R. Cousins, J. Am. Chem. Soc., 1965, 87, 1665-1669.

31. Z.-I. Yoshida and E. Osawa, J. Am. Chem. Soc., 1966, 88, 40194026.

32. A. R. Hirst and D. K. Smith, Chem. Eur. J., 2005, 11, 5496-5508

33. B. A. Simmons, C. E. Taylor, F. A. Landis, V. T. John, G. L. McPherson, D. K. Schwartz and R. Moore, J. Am. Chem. Soc., 2001, 123, 2414-2421.

34. M. Tata, V. T. John, Y. Y. Waguespack and G. L. McPherson, J. Am. Chem. Soc., 1994, 116, 9464-9470.

35. M. Tata, V. T. John, Y. Y. Waguespack and G. L. McPherson, $J$. Phys. Chem., 1994, 98, 3809-3817. 


\section{Supplementary Information}

Nitrochalcones as organogelators. Evidence of the involvement of nitro groups and solvent in gel formation

François-Xavier Simon, ${ }^{a}$ Thi-Thanh-Tam Nguyen, ${ }^{a}$ Marc Schmutz, ${ }^{a}$ Gero Decher, ${ }^{a}$ JeanFrançois Nicoud ${ }^{* b}$ and Philippe J. Mésini ${ }^{* a}$

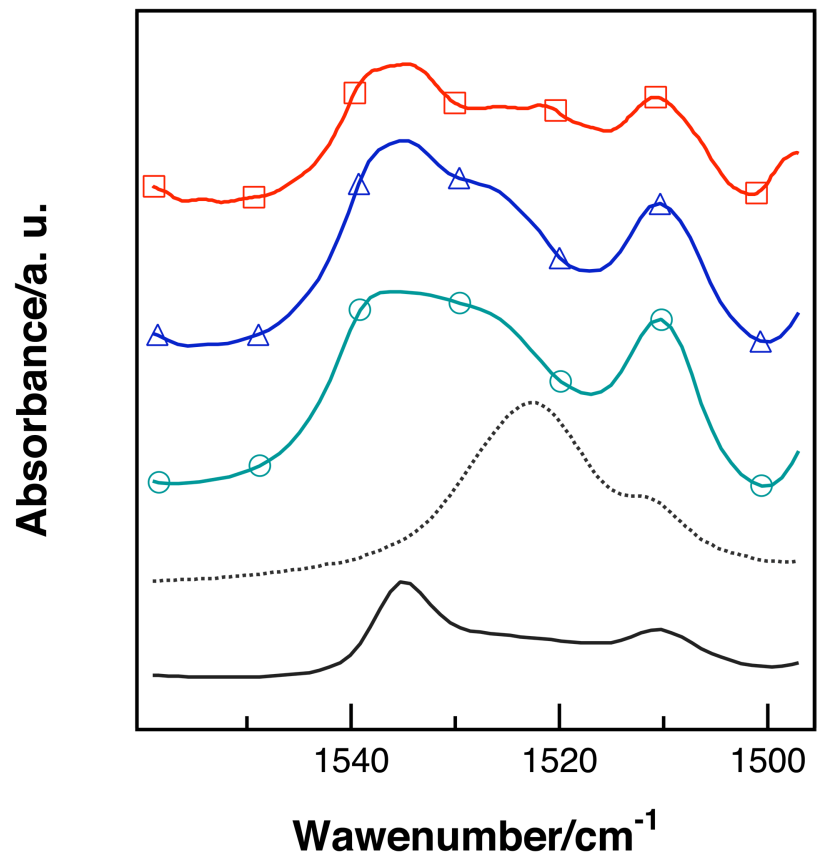

Fig. S2 FTIR of $\mathrm{C}_{12}-\mathrm{Ch}-\mathrm{NO}_{2} / \mathrm{BnOH}$ gel $(2 \%$ wt. $)$ in the $\mathrm{v}_{\mathrm{s}} \mathrm{NO}_{2}$ area. $\quad$ : gel in $\mathrm{BnOH}(2 \%$ wt $)$; dotted line : $\Delta:$ gel in ${ }^{\mathrm{t}} \mathrm{BuOAc}(2 \%$ wt. $)$; $\mathrm{O}:$ gel in $\mathrm{CCl} 4$ (4\% wt.); dotted line in solution in $\mathrm{CHCl}_{3}(0.17 \%$ wt.); plain line : solid (ATR-IR). 